\title{
Intraspecific functional trait variation and performance of Populous tremuloides
}

\author{
Florian Fort* \\ Institut National de la Recherche Agronomique, UMR 1248 AGIR, Castanet-Tolosan, France \\ ${ }^{*}$ Correspondence: florian.fort@toulouse.inra.fr \\ Edited by: \\ Inderiit, University of Delhi, India \\ Reviewed by: \\ Mark Van Kleunen, University of Konstanz, Germany
}

Keywords: fine root morphology, genetic variation, intraspecific variation, relative growth rate, specific leaf area, root tissue density, root functional trait

\section{A commentary on}

Intraspecific variation in root and leaf traits and leaf-root trait linkages in eight aspen demes (Populus tremula and P. tremuloides)

by Hajek, P., Hertel, D., and Leuschner, C. (2013). Front. Plant Sci. 4:415. doi: 10.3389/fpls.2013.00415

The fact that plant-trait and functionaltrait syndromes can describe plant growth strategies, and as a result their ecological requirements, has gained considerable importance in ecology (Grime et al., 1997; Westoby et al., 2002). At the global scale, the existence of a major axis of specialization among plants has been determined by measuring leaf functional traits; this axis highlights a fundamental tradeoff between rapid acquisition of resources and conservation of resources within wellprotected tissues (Díaz et al., 2004; Wright et al., 2004). Díaz et al. (2004) demonstrated that water and nutrient stresses lead to trait-syndrome convergence, with conservative species most present in stressful growth conditions, while acquisitive ones most present in to non-stressful growth conditions. This result highlight the functional traits capacity to explain species adaptation to different growth conditions. Moreover, despite the evidence of a large functional traits differentiation within species and the importance of trait variability within a species to establish itself in different habitats (Violle et al., 2012), functional strategies generally have been identified at the species level and did not incorporate within species traits variability.

The fact that functional traits measurement allowed the definition of plant strategies, and as a result their ability to develop biomass in a variety of growth conditions, led Garnier and Navas (2011) to recommend this approach for agricultural and forestry systems to maximize services of these types of production, and to reduce their environmental drawbacks. However, several questions remain: (i) Do the species used in forestry and agrosystems display different trait syndromes among genotypes?; (ii) Is trait-value variation among genotypes related to genetic differences? and (iii) Are the strategies related to performance of the genotype?

To answer these questions Hajek et al. (2013) test if leaf as well as root functional traits are related to Populus varieties performance. In order to do that, they grew seven demes, i.e. an assemblage of closely related individuals (Gilmor and Gregor, 1939), of two conspecific subspecies, the European Populus tremula and one deme of the North American P. tremuloides in monoculture stands in a common garden in the Solling Mountains (Germany). For each deme, roots were collected in the upper $30 \mathrm{~cm}$ of the mineral soil at a stem distance of $15-30 \mathrm{~cm}$ from 18 to 20 randomly chosen juvenile trees. Root functional traits, including specific root length (SRL, m. $\left.\mathrm{g}^{-1}\right)$, specific root area (SRA, $\mathrm{cm}^{2} \mathrm{~g}^{-1}$ ), root tissue density (RTD, $\mathrm{g} \mathrm{cm}^{-3}$ ), root tip abundance, root diameter, and $N$ content were measured on fine roots $(<2 \mathrm{~mm})$ according to Cornelissen et al. (2003). Simultaneously with root sampling, leaves were collected from the same trees to measure leaf area $\left(\mathrm{cm}^{2}\right)$, specific leaf area (SLA, $\mathrm{cm}^{2} \mathrm{~g}^{-1}$ ), and $\mathrm{N}$ and $\mathrm{C}$ contents.

Hajek et al. (2013) showed strong intraspecific variation in nearly all functional traits; only RTD did not vary among demes. These results highlight that although root traits can describe species' strategies well, they may also allow populations within a species to be differentiated. This interpretation is strengthened by the fact that despite the small number of demes considered, two roots traits (root tip abundance and RTD) and two leafs traits (leaf size and SLA) appeared to be linked to genetic variation among demes. Moreover, some demes showed particularly high within-deme trait variation, suggesting the existence of strong within-deme genetic diversity. This result challenge the idea that a species should be described by one trait value and opens interesting perspectives in plant breeding by highlighting the existence of strong within-species trait diversity linked to genetic differentiation, which is a prerequisite for breeding based on functional traits. The authors did not highlight links between above-ground relative growth rates (RGR) and root traits, while leaf traits appeared to be linked to the RGR but are poor predictors of it. They hypothesized that this was due to a stronger relation between root traits and below-ground RGR than above-ground RGR, showing the need for more whole-plant holistic studies to better understand plant functioning. These links were tested in a single growth environment. Root functional traits should be linked more to species performance under conditions where water and nutrient availability limits plant growth and thus where different root strategies should result in contrasting performance (Zhu et al., 2010).

In summary, study by Hajek et al. (2013) demonstrated the existence of significant intraspecific trait variation 
linked to genetic differences among demes. They also demonstrated that our knowledge about the links between traits and plant performance must be improve. It is hoped that the Hajek et al. (2013) study will stimulate more research efforts to clarify the relations among trait values, plant relatedness, plant performance and environmental factors, in order to let the concept of functional traits be functional in forestry and agronomy.

\section{REFERENCES}

Cornelissen, J. H. C., Lavorel, S., Garnier, E., Díaz, S., Buchmann, N., Gurvich, D. E., et al. (2003). A handbook of protocols for standardised and easy measurement of plant functional traits worldwide. Aust. J. Bot. 51, 335. doi: 10.1071/ BT02124

Díaz, S., Hodgson, J. G., Thompson, K., Cabido, M., Cornelissen, J. H. C., Jalili, A., et al. (2004). The plant traits that drive ecosystems: evidence from three continents. J. Veg. Sci. 15, 295. doi: 10.1111/j.1654-1103.2004.tb02266.x
Garnier, E., and Navas, M.-L. (2011). A trait-based approach to comparative functional plant ecology: concepts, methods and applications for agroecology. A review. Agron. Sustain. Dev. 32, 365-399. doi: 10.1007/s13593-011-0036-y

Gilmor, J. S.., and Gregor, J. W. (1939). Demes: a suggested new terminology. Nature 144, 333-333. doi: 10.1038/144333a0

Grime, J. P., Thompson, K., Hunt, R., Hodgson, J. G., Cornelissen, J. H. C., Rorison, H. I., et al. (1997). Integrated screening validates primary axes of specialisation in plants. Oikos 79, 259-281. doi: $10.2307 / 3546011$

Hajek, P., Hertel, D., and Leuschner, C. (2013). Intraspecific variation in root and leaf traits and leaf-root trait linkages in eight aspen demes (Populus tremula and P. tremuloides). Front. Plant Sci. 4:415. doi: 10.3389/fpls.2013.00415

Violle, C., Enquist, B. J., McGill, B. J., Jiang, L., Albert, C. H., Hulshof, C., et al. (2012). The return of the variance: intraspecific variability in community ecology. Trends Ecol. Evol. 27, 244-252. doi: 10.1016/j.tree.2011.11.014

Westoby, M., Falster, D. S., Moles, A. T., Vesk, P. A., and Wright, I. J. (2002). Plant ecological strategies: some leading dimensions of variation between species. Annu. Rev. Ecol. Syst. 33, 125-159. doi: 10.1146/annurev.ecolsys.33.010802.150452
Wright, I. J., Reich, P. B., Westoby, M., Ackerly, D. D., Baruch, Z., Bongers, F., et al. (2004). The worldwide leaf economics spectrum. Nature 428 , 821-827. doi: 10.1038/nature02403

Zhu, J., Brown, K. M., and Lynch, J. P. (2010). Root cortical aerenchyma improves the drought tolerance of maize (Zea mays L.). Plant. Cell Environ. 33, 740-749. doi: 10.1111/j.13653040.2009.02099.x

Received: 29 October 2013; accepted: 09 December 2013; published online: 24 December 2013.

Citation: Fort F (2013) Intraspecific functional trait variation and performance of Populous tremuloides. Front. Plant Sci. 4:527. doi: 10.3389/fpls.2013.00527 This article was submitted to Functional Plant Ecology, a section of the journal Frontiers in Plant Science.

Copyright (c) 2013 Fort. This is an open-access article distributed under the terms of the Creative Commons Attribution License (CC BY). The use, distribution or reproduction in other forums is permitted, provided the original author(s) or licensor are credited and that the original publication in this journal is cited, in accordance with accepted academic practice. No use, distribution or reproduction is permitted which does not comply with these terms. 